\title{
INTERNALIZATION OF RELIGIOUS VALUES IN EMPLOYEE PERFORMANCE
}

\author{
Diyah Wikan Rahmatika \\ Fakultas Ilmu Budaya (FIB) Universitas Gadjah Mada (UGM) Yogyakarta \\ Email: diyah.wikanrt@gmail.com \\ Muhammad Yusuf Hadiyatullah \\ Institut Agama Islam Darussalam (IAID) Ciamis-Jawa Barat \\ Dedeh Yulia \\ Institut Agama Islam Darussalam (IAID) Ciamis-Jawa Barat
}

\begin{abstract}
The Muslims have such a strong and fundamental work ethic because it boils down to faith, deals directly with God's power, and is a matter of life and death. A Muslim in every work must be earnest and energetic. In other words, it must be with a high work ethic so that the resulting performance would be more leverage because a Muslim is a more worker (smart-worker). This also applies in an organization or company such as Rabbani which is a company with an activity program that applies Islamic values. This research uses correlational research method, using quantitative approach. Data collection in this study used questionnaires, interviews, and documentation. Data analysis technique used is descriptive statistical analysis, assumption test using normality test, and hypothesis test by using simple linear regression analysis, and t test. Based on the results of this study can be seen that: 1) Islamic work ethic in Rabbani Group Tasikmalaya said good. This is evidenced by the average value of Islamic ethos work variables of 47.77 ; 2) employee performance in Rabbani Group Tasikmalaya is enough. This is evidenced by the average value of employee performance variables of $30.10 ; 3)$ the influence between variables based on the correlation coefficient of 0.373 means that the value belongs to the low level of relationship, that the work ethic of Islami and employee performance have correlation with the low level of relationship. While to see whether or not the influence of this research is done with $t$ test, which shows that $t$ arithmetic of 2.127 with a significance value of 0.042 so that the significance value of $0.042<0.05$ means there is a significant influence between Islamic work ethic variables on employee performance on Rabbani Group Tasikmalaya. Influence is obtained by $13.9 \%$ which means employee performance variables influenced by Islamic work ethic variables, while $86.1 \%$ influenced by other variables.
\end{abstract}

\begin{abstract}
Abstrak
Umat Islam memiliki etos kerja yang begitu kuat dan mendasar karena bermuara pada iman, berhubungan langsung dengan kekuasaan Tuhan, dan merupakan masalah hidup dan mati. Seorang muslim dalam setiap pekerjaannya harus bersungguhsungguh dan energik. Dengan kata lain harus dengan etos kerja yang tinggi agar kinerja yang dihasilkan akan lebih maksimal karena seorang muslim adalah pekerja yang lebih (smart-worker). Hal ini juga berlaku dalam sebuah organisasi atau perusahaan seperti Rabbani yang merupakan perusahaan dengan program kegiatan yang menerapkan nilai-nilai Islam. Penelitian ini menggunakan metode penelitian korelasional, dengan menggunakan pendekatan kuantitatif. Pengumpulan data dalam penelitian ini menggunakan angket, wawancara, dan dokumentasi. Teknik analisis data yang digunakan adalah analisis statistik deskriptif, uji asumsi menggunakan uji normalitas, dan uji hipotesis dengan menggunakan analisis regresi linier sederhana, dan uji t.
\end{abstract}


Berdasarkan hasil penelitian ini dapat diketahui bahwa: (1) Etos kerja Islami di Rabbani Group Tasikmalaya dikatakan baik. Hal ini dibuktikan dengan nilai rata-rata variabel etos kerja islami sebesar 47,77; (2) kinerja karyawan di Rabbani Group Tasikmalaya sudah cukup. Hal ini dibuktikan dengan nilai rata-rata variabel kinerja karyawan sebesar 30,10; (3) pengaruh antar variabel berdasarkan koefisien korelasi sebesar 0,373 artinya nilai tersebut tergolong dalam tingkat hubungan yang rendah, bahwa etos kerja Islami dan kinerja karyawan memiliki korelasi dengan tingkat hubungan yang rendah. Sedangkan untuk melihat ada atau tidaknya pengaruh penelitian ini dilakukan dengan uji t yang menunjukkan bahwa t hitung sebesar 2,127 dengan nilai signifikansi 0,042 sehingga nilai signifikansi 0,042 < 0,05 artinya terdapat pengaruh yang signifikan antara variabel etos kerja Islami. terhadap kinerja karyawan pada Rabbani Group Tasikmalaya. Pengaruh yang diperoleh sebesar 13,9\% yang artinya variabel kinerja karyawan dipengaruhi oleh variabel etos kerja islami, sedangkan 86,1\% dipengaruhi oleh variabel lain.

Keywords: Islamic Work Ethic, Islamic Values, Employee Performance

\section{Introduction}

A Muslim is required to be not only concerned with the afterlife or the world, but in the midst of both. This is like the word of God, namely:

"And look to that which Allah has bestowed upon you in the Hereafter, and do not forget your part from the (pleasures) of the world and do good (to others) as Allah has done good to you, and do not do mischief in (face) ) earth. Allah does not love those who do corruption ". (Q.S. Al-Qashash, 28: 77)

In order to obtain happiness in the world and the hereafter in a balanced way Islam teaches its people to work hard either in the form of worship or pious deeds. Hard work or in other words, called work ethic is an absolute requirement to be able to achieve the happiness of the world and the hereafter, because with a high work ethic will result in high performance as well. So that Islam gives great attention to hard work, because with hard work or work ethic happiness world and hereafter we can achieve.

Performance management allows individuals to express their views on what they should do, where they want to go and how they should be managed. The performance management process can be used to communicate and strengthen organizational strategies, values and norms and integrate individual and organizational goals.

Employees are the most important asset for the company. The quality of customer service depends on the service work ethic. Employees can learn how much they are performing through means of information, such as good comments from partners, but performance appraisals refer to a formal and structured system. The focus is to know how productive an employee is and whether it can perform the same or more effectively in the future, so that employees, organizations, communities all benefit.

From the above exposure can be seen that with a high work ethic in the end improve performance in work. So the application of the work ethic especially for the Islamic work ethic is very important role in achievement for performance in work.

In this study the authors reviewed the Rabbani Group Tasikmalaya, as has been known Rabbani is a garme company $\mathrm{n}$ which is engaged in retail Muslim fashion and tagline professor veil Indonesia. Rabbani is a company that has an activity program 
based on Islam, by applying the Islamic values that become mandatory and determined by the company to all elements of the company.

\section{Theoritical Review}

\section{The Concept of Ethos of Islamic Work}

Ethos derived from the Greek word, can mean something that is believed, how to do, attitude and perception of the value of work. From this word was born what is called ethic that is, guidance, moral and behavior, or also known etiquette which means polite manner. So with this ethical word, known the term business ethics is a way or guideline of behavior in running a business and so forth (Tasmara, 1995: 25).

Working for a Muslim is a genuine effort, devoting all of his assets, thoughts, and dhikr to actualize or manifest himself as a servant of God who must subdue the world and establish himself as part of the best society (khoirou "m" ah) or in other words can also be said that only by human labor is humanizing itself.

The Islamic work ethic can be interpreted as a genuine effort by mobilizing all of its assets, minds, and efforts in expressing itself as a servant of God who must subdue the world and position itself as part of the best society. By working humans can humanize him, because by working humans can actualize themselves so as to be able to place itself as part of the community.

As a Muslim, we need to know the characteristics of people who have and appreciate this Islamic work ethic. It will appear in his attitude and behavior based on a deep conviction that work is a form of worship, a calling and commandment of God that will glorify him, humanizing himself as part of the chosen man (khairu ummah). The characteristics of this Islamic work ethic include:

a) Has leadership soul

b) Always counting

c) Appreciate time

d) He is never satisfied with doing good (positive improvments), being satisfied in doing good, is a sign of the death of creativity.

e) Life saves and efficient

f) Has entrepreneurial soul (entrepreneurship)

g) Have a competing instinct and compete

h) Desire for mandiri (independent)

i) Thirst to have the nature of scientific

j) Universal macro insight

k) Paying attention to health and nutrition

l) Resilient and disappointing

m) Oriented to productivity

n) Enrich silaturrahmi network

o) Employee performance

p) Understanding employee performance (Alisahbana, 1998:3)

HR performance is a term derived from the word job perfomance or actual perfomance (achievement of work or achievement actually achieved someone). The definition of employee performance according to Mangkunegara (2006: 9), "Employee performance (work performance) is the work of quality and quantity achieved by an 
employee in performing their duties in accordance with the responsibilities given to him.

In the view of Islam, performance (work) associated with everything that has been done by an individual relevant to a certain standard (Amaliah, et.al. 2013: 167). With regard to human performance, Allah reveals it in the form of reward and punishment, as the word of God describes: He said: "As for those who persecute, then We will punish him, then He returns to his Lord, then the Lord punishes him with unequaled doom, As for those who believe and do righteous deeds, So for him the best reward in return, and We will direct him (command) which is easy from our commandments ". (Q.S. Al-Kahf, 18: 87-88)

Davis \& Newstrom (2000: 13), holds that the factors that influence the achievement of performance is the ability factor (ability) and motivation factors (motivation) which formulates that:

a) Human perfomance = ability $\mathrm{x}$ motivation

b) Motivation $=$ attitude $\mathrm{x}$ situation

c) Ability $=$ knowledge $\mathrm{x}$ skill

d) Ability factor

Soelaiman (2007: 112) states the ability is the nature of the birth or learned that allows a person who can complete the work, either mentally or physically. Individual ability is essentially composed of two factors: intellectual ability and physical ability. According to Fahmi (2014: 87), "Motivation is a behavioral activity that works in an effort to meet the racing god-desirable needs ". If associated with performance then the motivation is defined as an attitude (attitude) leaders and employees of the situation of work (situation) in the environment organization.

\section{Methods}

The type and method of this research use correlational research with quantitative approach and use survey research method. Correlational research aims to detect the extent to which variations in a factor relate to variations in one or more other factors based on the correlation coefficient (Suryabrata, 2004: 82). Quantitative research is a research used to examine the population or a particular sample, data collection using research instruments, quantitative data analysis / statistics, with the aim to test the hypothesis that has been established (Sugiyono, 2014: 11).

Research is generally conducted on a representative population or sample. This research was conducted in Rabbani Group Tasikmalaya. The population that will be used as research object is all employees that exist in Rabbani Group Tasikmalaya that is 31 people.

There are two main things that affect the quality of research data, namely the quality of research instruments and the quality of data collection. In this research data collection techniques used by the author are questionnaire, interview, document analysis. Data analysis conducted in this study, including using descriptive statistics, normality test, product moment correlation coefficient (pearson), $t$ test, coefficient of determination, and simple regression analysis.

Descriptive statistics are statistics used to analyze data by way of describing or describing data that has been accumulated as is without intending to make conclusions that apply to the public or generalization. 
Assumption test in this study using normality test is intended to determine whether the symptoms studied have a normal distribution or not. If the distribution of variables form a normal curve then it can be done analysis to test the hypothesis. The normality testing criterion is when the significance value> alpha, then the data is normally distributed.

Product Moment or Pearson correlation is used to determine the relationship between variables if the data used has an interval or ratio scale. The rationale of product moment correlation analysis is the change between variables, meaning if the change of a variable followed the change of other variables then the two variables are mutually correlated (Suliyanto, 2011: 16).

The $t$ test is used to find out whether the independent variable has significant effect or not to the dependent variable. $\mathrm{T}$ test is done by comparing the value of $\mathrm{t}$ arithmetic with $t$ table. A variable will have a meaningful influence if the value of $t$ arithmetic variable is greater than the value of $t$ table.

The coefficient of determination $\left(\mathrm{R}^{2}\right)$ is used to analyze how much percentage of independent variable contribution to the dependent variable (Kasmadi and Sunariah, 2014: 93). The coefficient of determination is between zero and one. The small value of $\mathrm{R}^{2}$ means that the ability of independent variables to explain the variation of the dependent variable is very limited.

In testing the hypothesis, this study uses a simple linear regression equation. This analysis is used with reason to know influence between independent variable with dependent variable, that is work ethic of Islami (X) to employee performance (Y).

\section{Result and Discussion}

Rabbani Tasikmalaya Group has 31 employees, from questionnaires distributed as many as 31 questionnaires that returned only 30 questionnaires, 1 questionnaire that did not return because the employee was in the off period of work when the research was conducted so that the questionnaire was not filled by the employee.

Grouping of respondents by sex, it is known that the majority of respondents Rabbani Tasikmalaya Group is female that is as many as 24 people or $80 \%$ while the rest are male respondents as much as 6 people or $20 \%$. Grouping of respondents by age shows that most employees between the ages of 21 - 26 years are as many as 15 people or 50\%. While others aged $15-20$ years are 7 people or $23.3 \%$, aged 27 to 32 years as many as 5 people or $16.7 \%, 33$ to 38 years old as many as 1 person or $3.3 \%$, and aged 39 - 44 years ie as many as 2 people or $6.7 \%$. This shows that most of the employees working in Rabbani Tasikmalaya Group are between 21 - 26 years old.

Grouping of respondents by education is known that some be sar employees Rabbani Group Tasikmalaya educated high school / equivalent as many as 26 people or $86.7 \%$. While the others are educated Diploma that is as much as 2 people or $6.7 \%$, and Bachelor is as much as 2 people or $6.7 \%$. Based on data from questionnaire of Islamic work ethic, the average value obtained from Islamic work ethic is 47,77 or $79,62 \%$. So that the work ethic of Islami in Rabbani Group Tasikmalaya equal to 79,62\% say good.

Based on the results of the employee performance questionnaire, then the average score obtained from the employee performance variable is 30.10 or $75.25 \%$. So the employee performance in Rabbani Group Tasikmalaya equal to 75,25\% is enough. Statistical Test Analysis 
From the results of one-sample normality test kolmogrov-smirnov known that all data significance is above the error rate of $5 \%$ or $0.200>0.05$ so it can be expressed all the data instruments distributed normally. Based on the research results can be seen that between variables $\mathrm{X}$ and variable $\mathrm{Y}$ there is a correlation of 0.373 . Furthermore, to determine the level of correlation between the two variables, we can interpret the correlation coefficient in accordance with the guidelines as follows:

Based on these guidelines, the correlation coefficient number 0.373 included into the interval $0.20-0.399$ means it has a low correlation. Thus, the influence of Islamic work ethic on employee performance in Rabbani Group Tasikmalaya has a low level of relationship. Based on argument above shows the test results against the hypothesis as follows: $\mathrm{Ho}=$ there is no significant influence between the variables of Islamic work ethic on employee performance. $\mathrm{Ha}=$ there is a significant influence between the variables of Islamic work ethic on employee performance. By criteria if significance> 0,05 then Ho accepted and if significance $<0,05$ then $\mathrm{Ha}$ accepted, from result of test above show that $t$ count equal to 2,127 with value signifikansi 0,042 where value less than 0,05 so value signifikansi $0,042<0.05$ then $\mathrm{Ha}$ accepted, meaning there is a significant influence between the variables of Islamic work ethic on employee performance.

Coefficient of determination equal to 0,139 mean that variation of employee performance can be explained by variation of work ethic of Islam equal to $13,9 \%$ or variable of work ethic of Islami affecting employee performance equal to $13,9 \%$, while the rest equal to $86,1 \%$ influenced by other variable not explained in this research.

Simple Regression Analysis

Looking at statistic output obtained by constant equal to 18,979 and coefficient value for Islamic work ethic variable equal to 0,233 so that model of regression equation obtained $\mathrm{Y}=18.979+0.233 \mathrm{X}$.

From the test results conducted value of correlation coefficient between work ethic of Islami to employee performance at Rabbani Group of Tasikmalaya that is equal to 0,373 which means that value belong to low level of relationship. This means that the Islamic work ethic and employee performance have a correlation with low levels of relationships. As for influence yes done with $t$ test, showed that $t$ arithmetic of 2.127 with a significance value of 0.042 so that the significance value of $0.042<0.05$ means that according to the 30 populations analyzed there is sufficient evidence of a significant influence between Islamic work ethic variables on employee performance in Rabbani Group Tasikmalaya. The effect is $13.9 \%$, which means employee performance variable is influenced by Islamic work ethic variable, while $86,1 \%$ of employee performance variable is influenced by other variable which not discussed in this research.

Islamic work ethos should be considered in improving employee performance because Islamic work ethic affect employee performance seen in regression equation that is $\mathrm{Y}=18,979+0,233 \mathrm{X}$, meaning from this equation is if $\mathrm{X}$ (work ethic of Islami) $\mathrm{O}$ value then Y (employee performance) have value of 18.979. In this case even if one does not have an Islamic work ethic but still has performance due to other unidentified factors in the research, and if X (Islamic work ethic) rises 1 unit then Y (employee performance) will rise by 0.233 units. This shows the higher the ethos of Islamic work then the performance of a person will also be higher. This can be seen from the results of respondents' answers on each item statement of Islamic work ethic, with the average 
value obtained from the work ethic of Islami is 47.77 or $79.62 \%$. Based on the guidelines proposed by Arikunto, the application of Islamic work ethic in Rabbani Group Tasikmalaya amounted to $79.62 \%$ said to be good.

Thus it can be concluded that the application of Islamic work ethic in Rabbani Tasikmalaya Group is said to be good, so that with the work ethic of Islami can be one factor that can affect employee performance in Rabbani Group Tasikmalaya.

This research may be an input for the company Rabbani Group Tasikmalaya in improving employee performance through the application of the concept of work ethic of Islami. Future research is expected to emphasize factors that affect employee performance with other Islamic side such as creating Islamic organization culture and Islamic work environment, because this factor is not emphasized in this research.

\section{Conclusion}

Based on the research that has been raised above can be concluded: The Islamic work ethic in Rabbani Group Tasikmalaya is said to be good. This is evidenced by the average value of Islamic ethos work variables of 47.77 from the ideal value of 60 or 79.62\%. Employee performance in Rabbani Group Tasikmalaya is enough. This is evidenced by the average value of employee performance variable of 30.10 from the ideal value of 40 or $75.25 \%$. The results of testing conducted by the correlation coefficient between Islamic work ethic on employee performance in Rabbani Group Tasikmalaya that is equal to 0.373 which means that the value belongs to the low level of relationship. This means that the Islamic work ethic and employee performance have a correlation with low levels of relationships. As for the effect is done by $t$ test, which shows that $t$ arithmetic of 2.127 with a significance value of 0.042 where the value is less than 0.05 so that the significance value of $0.042<0.05$ means that according to 30 populations analyzed there is enough evidence of a significant influence between variables Islamic work ethic on employee performance in Rabbani Group Tasikmalaya. The effect is $13.9 \%$, which means employee performance variable is influenced by Islamic work ethic variable, while $86,1 \%$ of employee performance variable is influenced by other variable which not discussed in this research.

\section{REFERENCES}

Davis, Keith \& Newstrom, Jhon W (ed). (2000). Behavior in the organization, (Interpreter Agus Darma). Jakarta: Erland.

Fahmi, Irham. (Ed.). (2014). Introduction to human resource management concepts and performance. Jakarta: Media Discourse Partners.

Ima, Amaliah., Et.al. (2013). The influence of Islamic values on work performance. Mimbar, 29 (2), 165-167.

Kasmadi \& Sunariah, Nia Siti. (2014). A modern guide to quantitative research. Bandung: Alfabeta.

Mangkunegara, A.A. Anwar Prabu. (Ed.). (2006). Evaluation of HR performance (second printing). Bandung: PT Refika Aditama.

Soelaiman. (2007). Performance management is an effective step to build, control and evaluate work. Jakarta: PT. Intermedia Personnel Utama. 
Sugiyono. (Ed.). (2014). Quantitative, qualitative, and combination methods (mixed methods) (fifth mold). Bandung: CV. Alfabeta.

Suliyanto. (Ed.). (2011). Econometrics applied theory and application with SPSS. Yogyakarta: Andi.

Suryabrata, Sumadi. (2004). Research methodology. Jakarta: PT Rajagrafindo Persada. Tasmara, Toto. (Eds.). (1995). Muslim personal work ethic. Solo: PT. Amanah Bunda Sejahtera.

Ya'qub, Hamzah. (2001). Islamic work ethic. Jakarta: Guidance of Science Jaya. 